\title{
Risk factors of stunting in toddler aged 24-59 month
}

\author{
Melba Riska Utami Hutabarat ${ }^{1 *}$, Irwanto ${ }^{2}$, Sulistiawati ${ }^{3}$ \\ ${ }^{1}$ Program Studi Kebidanan Fakultas Kedokteran Universitas Airlangga Surabaya, \\ Indonesia, ${ }^{2}$ Departemen IImu Anak RS Dr. Soetomo Surabaya, Indonesia, ${ }^{3}$ Departemen \\ IImu Kesehatan Masyarakat FK Universitas Airlangga Surabaya, Indonesia
}

\begin{abstract}
Stunting is a chronic condition that describes growth retardation due to long-term malnutrition. Prevalenced of stunting in Cempaka subdistrict in 2017 reached $51.25 \%$ and the stunting incidence was widely found in toddler aged 24 - 59 month. The purpose of study was to analyze the risk factors of stunting in toddler age 24 - 59 month in Cempaka subdistrict, Banjarbaru. The research was an observational analytic with case control approached. The sample was 200 peoples included mothers and toddlers aged 24-59 months according to the inclusion criteria. Subject selection by cluster random sampling for selected the group's sample and simple random sampling for selected its sample. The data was tested using Chi Square and logistic regression at significance level $\alpha=0.05$. This analysis was performed to find the association of stunting with selected factors. The resulted of the multivariate analysis showed short birth's length had ( $p=0.00 ;$ OR 14.1) and the age 24-36 month had ( $p=0.01 ;$ OR 1.6) while mother's height, sex, socioeconomic status, parent's educational status, mother's age married, mother's malnutrition status, birth weight, exclusive breastfeeding and complementary food's time is not a factor in stunting. The conclusion of this study that short birth's length and aged $24-36$ month are the most dominant risk factor of stunting in toddler aged 24-59 month.
\end{abstract}

Keywords: toddler aged 24-59 month, stunting, risk factors, malnutrition

Stunting merupakan kondisi kronis yang menggambarkan pertumbuhan terhambat karena malnutrisi jangka panjang. Prevalensi stunting di Kecamatan Cempaka Kota Banjarbaru pada tahun 2017 yaitu $51,25 \%$ dan umumnya banyak terjadi pada balita usia $24-59$ bulan. Tujuan penelitian ini untuk menganalisis faktor risiko stunting pada balita usia 24 - 59 bulan di Kecamatan Cempaka Kota Banjarbaru. Penelitian ini merupakan penelitian analitik observasional dengan pendekatan case control. Jumlah sampel 200 orang meliputi ibu dan balita usia 24 - 59 bulan sesuai dengan kriteria inklusi. Sampling menggunakan cluster random sampling untuk memilih kelompok sampel dan simple random sampling untuk memilih sampel. Data yang terkumpul diuji dengan menggunakan Chi Square dan regresi logistik pada tingkat kemaknaan $\alpha=0,05$. Hasil analisis multivariat menunjukkan panjang badan lahir pendek memiliki ( $p=0,00 ;$ OR 14,1) dan kelompok usia $24-36$ bulan memiliki $(p=0,01 ; O R$ 1,6) sedangkan tinggi badan ibu, jenis kelamin balita, pendapatan keluarga, pendidikan orang tua, usia menikah ibu, riwayat status nutrisi hamil ibu, riwayat berat lahir, riwayat ASI eksklusif dan riwayat waktu pemberian makanan pendamping ASI bukan merupakan faktor penyebab stunting. Kesimpulan penelitian ini adalah panjang lahir pendek dan kelompok usia $24-36$ bulan merupakan faktor risiko stunting paling dominan pada balita usia 2459 bulan.

Kata Kunci: balita usia 24 - 59 bulan, stunting, faktor resiko, malnutrisi

Korespondensi Penulis : Melba Riska Utami Hutabarat (email : medicworld3@gmail.com) 


\section{Pendahuluan}

Stunting merupakan salah satu permasalahan gizi pada balita yang terjadi di Indonesia. Stunting merupakan kondisi gagal tumbuh dan masalah gizi kronis yang disebabkan oleh asupan gizi yang kurang akibat pemberian makanan yang tidak sesuai dengan kebutuhan dalam jangka waktu yang lama (Schmidt, 2014). Kejadian stunting pada janin hingga anak berusia dua tahun dapat meningkatkan angka kematian bayi dan anak serta menurunkan sistem imun. Penderita stunting mudah sakit, memiliki postur tubuh yang tidak maksimal, serta memiliki produktivitas yang rendah pada saat dewasa (Aguayo \& Menon, 2016). Selain itu, stunting berdampak pada tingkat kecerdasan, kerentanan terhadap penyakit, menurunkan produktivitas sehingga dapat menghambat pertumbuhan ekonomi serta dapat meningkatkan kemiskinan dan ketimpangan di Indonesia (Kementerian Kesehatan, 2018). Keadaan ini dipresentasikan dengan nilai z-score tinggi badan menurut umur (TB/U) kurang dari -2 standar deviasi (SD) berdasarkan standar pertumbuhan menurut WHO (Hairunis, Rohmawati, \& Ratnawati, 2016). Menurut Rahmi CN., et al stunting pada balita banyak terjadi pada tahapan usia $24-59$ bulan (Rachmi, Agho, Li, \& Baur, 2016).
Status gizi kurang yang bersifat kronik disebabkan malnutrisi dapat memperburuk kondisi suatu penyakit. Balita yang menderita malnutrisi umumnya meninggal karena penyakit seperti diare, pneumonia, malaria, measles dan AIDS (Christian, Mullany, Hurley, Katz, \& Black, 2015) Penyebab paling umum di dunia malnutrisi adalah buruknya kualitas makanan, bayi yang lahir dari keluarga miskin, asupan ASI dan pola asuh seperti pemberian ASI tidak optimal, kekurangan asupan mikronutrien seperti vitamin A atau zinc dan penyakit infeksi berulang, adanya parasit pada organ pencernaan. Malnutrisi balita juga menggambarkan kondisi yang saling terkait terhadap aspek demografi, aspek lingkungan, aspek sosio ekonomi, karakteristik orang tua, kualitas rumah tangga dan akses ke pelayanan kesehatan (Chowdhury et al., 2016).

Pada tahun 2017, jumlah stunting di dunia berkisar 22,2\% (Rachmi et al., 2016) sedangkan di Indonesia dari data Riskesdas tahun 2018 yaitu 30,8\% (Kemenkes RI, 2018). Di Kecamatan Cempaka Kota Banjarbaru Provinsi Kalimantan Selatan pada tahun 2016 prevalensi stunting sebesar 18,5\% dan tahun 2017 meningkat tajam yaitu $51,25 \%$ dari jumlah sampel sasaran 400 balita (Dinkes Kota Banjarbaru, 2015; Dinkes Kota Banjarbaru, 2017). Masalah balita pendek menggambarkan adanya masalah gizi kronis, 
dipengaruhi dari kondisi ibu atau calon ibu, masa janin, dan masa bayi atau balita, termasuk penyakit yang diderita selama masa balita. Seperti masalah gizi lainnya, tidak hanya terkait masalah kesehatan, namun juga dipengaruhi berbagai kondisi lain yang secara tidak langsung mempengaruhi kesehatan (InfoDATIN, 2016). Berdasarkan permasalahan di atas peneliti ingin meneliti faktor risiko stunting pada balita usia 24

- 59 bulan di Kecamatan Cempaka Kota Banjarbaru Provinsi Kalimantan Selatan.

\section{Metode}

Rancangan penelitian ini adalah analitik observasional dengan desain case control. Populasi penelitian adalah semua balita usia 24 59 bulan di Puskesmas Cempaka Kota Banjarbaru.Penelitian dilakukan di wilayah Puskesmas Cempaka pada bulan Februari 2019. Teknik sampling yang digunakan adalah cluster random sampling untuk memilih kelompok sampel yaitu posyandu dan simple random sampling untuk sampel individu yaitu balita posyandu dengan jumlah sampel dalam masingmasing kelompok kasus dan kontrol sebesar 100 subjek, sehingga didapatkan jumlah keseluruhan subjek sebesar 200 subjek yang memenuhi kriteria inklusi. Responden dalam penelitian ini adalah ibu balita yang terpilih menjadi subjek.
Pengumpulan data dilakukan dengan wawancara terhadap responden menggunakan lembar pengumpul data dan pengukuran antropometri ibu dan balita menggunakan alat ukur microtoise. Setelah data ditabulasi dilakukan analisis univariat, bivariat dan multivariat. Uji Chi Square digunakan untuk analisis bivariat dengan confident interval (Cl) 95\%, tingkat kemaknaan pada penelitian ditetapkan dengan nilai $p<0,05$ dan besar risiko (OR). Analisis multivariat dalam penelitian ini menggunakan metode regresi logistik. Tujuan penelitian ini untuk menganalisis hubungan faktor risiko terhadap stunting pada balita usia $24-59$ bulan.

\section{Hasil dan Pembahasan \\ Karakteristik Sampel}

Dari total jumlah sampel penelitian pada sampel kasus dan kontrol sebanyak 200 subjek. Sebaran usia anak balita pada kelompok kasus dan kontrol sebagian besar berada pada rentang umur 24 - 36 bulan. Kelompok balita stunting didominasi oleh anak balita berjenis kelamin perempuan dengan persentase $51 \%$ dan pada kelompok anak balita tidak stunting didominasi jenis kelamin laki - laki dengan persentase $54 \%$. 
Tabel 1. Karakteristik Balita pada Kelompok Balita Stunting dan Kelompok Balita Tidak Stunting

\begin{tabular}{|c|c|c|c|c|c|c|c|}
\hline & \multirow{2}{*}{ Variabel } & \multicolumn{2}{|c|}{ Stunting } & \multicolumn{2}{|c|}{ Tidak Stunting } & \multirow{2}{*}{$P$} & \multirow{2}{*}{$\begin{array}{c}\text { OR } \\
(95 \% \mathrm{Cl})\end{array}$} \\
\hline & & $\mathrm{n}$ & $\%$ & $\mathrm{n}$ & $\%$ & & \\
\hline \multirow[t]{3}{*}{1} & Jenis Kelamin Balita & & & & & & \\
\hline & - Perempuan & 51 & 51 & 46 & 46 & \multirow{2}{*}{0,47} & 1,222 \\
\hline & - Laki - Laki & 49 & 49 & 54 & 54 & & $(0,701-2,129)$ \\
\hline \multirow[t]{4}{*}{2} & Usia Balita & & & & & \multirow{4}{*}{0,01} & \\
\hline & - $24-36$ bulan & 57 & 57 & 40 & 40 & & \\
\hline & - $\quad 37-48$ bulan & 26 & 26 & 27 & 27 & & - \\
\hline & - $\quad 49-59$ bulan & 17 & 17 & 33 & 33 & & \\
\hline \multirow[t]{3}{*}{3} & Berat Badan Lahir & & & & & \multirow{3}{*}{0,80} & \\
\hline & - $\quad B B L R$ & 8 & 8 & 9 & 9 & & $\begin{array}{c}0,8 / 9 \\
(025-2379)\end{array}$ \\
\hline & - Normal & 92 & 92 & 91 & 91 & & \\
\hline \multirow[t]{3}{*}{4} & Panjang Badan Lahir & & & & & \multirow{3}{*}{0,00} & \\
\hline & $-\quad<48 \mathrm{~cm}$ & 83 & 83 & 26 & 26 & & $\begin{array}{c}0,0 / 2 \\
(0,036-0143)\end{array}$ \\
\hline & $-\quad \geq 48 \mathrm{~cm}$ & 17 & 17 & 74 & 74 & & \\
\hline \multirow[t]{4}{*}{5} & ASI Eksklusif & & & & & \multirow{4}{*}{0,20} & \\
\hline & - ASI Eksklusif & 57 & 57 & 48 & 48 & & 0,759 \\
\hline & - Parsial ASI & 29 & 29 & 41 & 41 & & $(0,327-1,765)$ \\
\hline & - Tidak ASI Eksklusif & 14 & 14 & 11 & 11 & & \\
\hline \multirow[t]{3}{*}{6} & Waktu Pemberian Makanan Pendamping ASI & & & & & \multirow{3}{*}{0,22} & \\
\hline & $-<6$ bulan & 72 & 72 & 64 & 64 & & $(0.796-2.630)$ \\
\hline & $->6$ bulan & 28 & 28 & 36 & 36 & & \\
\hline
\end{tabular}

Pada tabel 1 sebagian besar balita yang diteliti memiliki riwayat berat lahir normal dengan persentase $92 \%$ pada balita stunting dan $91 \%$ pada balita normal. Pada variabel riwayat panjang badan lahir didapatkan bahwa balita stunting memiliki persentase terbanyak riwayat panjang lahir $<48 \mathrm{~cm}$ dengan persentase $83 \%$ dan balita tidak stunting hanya $26 \%$. Pada sebaran riwayat ASI didominasi riwayat ASI Eksklusif dengan persentase pada kelompok balita stunting $57 \%$ dan balita tidak stunting dengan persentase $48 \%$. Sedangkan riwayat waktu pemberian Makanan Pendamping ASI didominasi $<6$ bulan dengan persentase pada kelompok balita stunting $72 \%$ dan balita tidak stunting $64 \%$.

Berdasarkan tabel 2 dapat diketahui bahwa tinggi badan ibu balita didominasi tinggi badan $\geq$ $145 \mathrm{~cm}$ pada kelompok balita stunting dengan persentase $78 \%$ dan balita tidak stunting $87 \%$. Pada variabel status pendidikan ibu dan ayah didominasi pendidikan dengan kategori rendah pada dua kelompok sampel tersebut. Sedangkan untuk variabel usia menikah ibu didominasi usia $\geq$ 18 tahun pada kelompok balita stunting dengan persentase $64 \%$ dan balita tidak stunting71\%. Pada variabel status nutrisi hamil ibu sebagian besar pada kategori $\geq 23,5 \mathrm{~cm}$ dengan 
persentase pada kelompok balita stunting $85 \%$ dan kelompok balita tidak stunting $75 \%$. Hasil yang tidak terlalu berbeda juga didapatkan pada variabel pendapatan keluarga dimana kedua kelompok sampel tersebut didominasi status pendapatan keluarga yang < Rp. 2.454.671 dengan persentase pada kelompok balita stunting $80 \%$ dan balita normal $77 \%$.

Tabel 2. Sosial Ekonomi Keluarga pada Kelompok Balita Stunting dan Kelompok Balita Tidak Stunting

\begin{tabular}{|c|c|c|c|c|c|c|c|}
\hline \multirow{2}{*}{ Variabel } & & \multicolumn{2}{|c|}{ Stunting } & \multicolumn{2}{|c|}{ Tidak Stunting } & \multirow{2}{*}{$P$} & \multirow{2}{*}{$\begin{array}{l}\text { OR } \\
(95 \% \mathrm{Cl})\end{array}$} \\
\hline & & $\mathrm{n}$ & $\%$ & $\mathrm{n}$ & $\%$ & & \\
\hline \multirow[t]{3}{*}{1} & Tinggi Badan Ibu & & & & & & \\
\hline & $-\quad<145 \mathrm{~cm}$ & 22 & 22 & 13 & 13 & & 1,888 \\
\hline & $-\quad \geq 145 \mathrm{~cm}$ & 78 & 78 & 87 & 87 & 0,09 & $(0,891-3,999)$ \\
\hline \multirow[t]{3}{*}{2} & Status Pendidikan Ibu & & & & & & \\
\hline & - $\quad$ Rendah & 66 & 66 & 70 & 70 & 0,54 & 0,832 \\
\hline & - $\quad$ Tinggi & 34 & 34 & 30 & 30 & & $(0,459-1,508)$ \\
\hline \multirow[t]{3}{*}{3} & Status Pendidikan Ayah & & & & & & \\
\hline & - Rendah & 71 & 71 & 69 & 69 & 0,75 & 1,100 \\
\hline & - $\quad$ Tinggi & 29 & 29 & 31 & 31 & & $(0,001-2,013)$ \\
\hline \multirow[t]{3}{*}{4} & Usia Menikah Ibu & & & & & & \\
\hline & $-\quad<18$ tahun & 36 & 36 & 29 & 29 & 0,29 & $1,3 / 1$ \\
\hline & $-\quad \geq 18$ tahun & 64 & 64 & 71 & 71 & & $(0,100-2,495)$ \\
\hline \multirow[t]{3}{*}{5} & Status Nutrisi Hamil Ibu & & & & & & \\
\hline & $-\quad<23,5 \mathrm{~cm}$ & 15 & 15 & 22 & 22 & 0,20 & $\begin{array}{l}0,0<0 \\
(0,303-1291)\end{array}$ \\
\hline & - $\quad \geq 23,5 \mathrm{~cm}$ & 85 & 85 & 78 & 78 & & \\
\hline \multirow[t]{3}{*}{6} & Pendapatan Keluarga & & & & & & \\
\hline & - $\quad<$ Rp. 2.454 .671 & 80 & 80 & 77 & 77 & 0,60 & $(0.608-2.349)$ \\
\hline & - $\quad \geq$ Rp. 2.454 .671 & 20 & 20 & 23 & 23 & & \\
\hline
\end{tabular}

Variabel yang diikutsertakan dalam analisa badan lahir, riwayat waktu pemberian multivariat adalah variabel yang memiliki Makanan Pendamping ASI dan riwayat nilai $p<0,25$ yaitu usia balita, panjang status nutrisi hamil ibu.

\begin{tabular}{|c|c|c|c|c|c|}
\hline \multirow{2}{*}{ Variabel } & \multirow{2}{*}{ Slope } & \multirow{2}{*}{ Nilai $p$} & \multirow{2}{*}{ OR } & \multicolumn{2}{|c|}{$95 \% \mathrm{Cl}$ for EXP (B) } \\
\hline & & & & Lower & Upper \\
\hline Panjang Badan Lahir & 2,648 & 0,000 & 14,130 & 6,989 & 28,565 \\
\hline Usia Balita & 0,524 & 0,015 & 1,689 & 1,106 & 2,581 \\
\hline Constant & $-4,739$ & 0,000 & & & \\
\hline
\end{tabular}

Berdasarkan tabel 3 bahwa variabel yang secara signifikan memiliki pengaruh terhadap kejadian stunting adalah variabel riwayat panjang badan lahir $<48 \mathrm{~cm}$ dengan 
nilai OR 14,130 dan variabel usia $24-36$ bulan dengan nilai OR 1,689. Diantara kedua variabel tersebut panjang badan lahir $<48$ $\mathrm{cm}$ memiliki pengaruh paling besar sebagai penyebab stunting pada balita usia $24-59$ bulan di Puskesmas Cempaka Kota Banjarbaru.

\section{Pembahasan}

Panjang badan yang jauh di bawah ratarata lahir disebabkan karena sudah mengalami retardasi pertumbuhan saat dalam kandungan. Retardasi pertumbuhan saat masih dalam kandungan menunjukkan kurangnya status gizi dan kesehatan ibu pada saat hamil sehingga menyebabkan anak lahir dengan panjang badan yang kurang (Ni'mah \& Nadhiroh., 2015). Hasil penelitian Nurillah di Bekasi menunjukkan bahwa panjang badan lahir berhubungan bermakna dengan pertumbuhan dan perkembangan anak. Terlihat bahwa anak dengan panjang badan lahir pendek dengan tumbuh kembang yang tidak normal persentasenya lebih besar (66,7\%) dibandingkan yang panjang badan lahir normal $(33,8 \%)$ (Amaliah, Sari, \& Suryaputri, 2016). Berbeda dengan penelitian yang dilakukan oleh Kukuh di Semarang Timur bahwa panjang badan lahir bukan merupakan faktor risiko stunting dikarenakan dalam penelitiannya tidak dilihat seperti riwayat kehamilan, asupan makan anak maupun pola asuh (Eka, 2013). Anak yang lahir dengan panjang badan lahir pendek memang lebih berisiko untuk tumbuh stunting dibanding anak yang lahir dengan panjang badan normal, tetapi selama anak tersebut mendapatkan asupan yang memadai dan terjaga kesehatannya, maka kondisi panjang badan lahir yang pendek dapat dikejar dengan pertumbuhan seiring bertambahnya usia anak (Cutland et al., 2017).

Anak balita yang berumur diatas 24 bulan 4 kali lebih berisiko untuk menjadi stunting daripada anak dibawah 24 bulan $(A O R=3.97[95 \% \mathrm{Cl}, 1.30-12.11]$ (Desalegn, Kinfe, Fikre, \& Bosha, 2016). Pada usia tahun kedua ada penurunan sedikit demi sedikit masukan kalori balita persatuan berat badan. Pada masa ini balita memiliki kecenderungan kurang suka sementara pada makanan tertentu atau bahkan pada makanan pada umumnya apabila orang tua tidak memahami fase ini, terutama penurunan kebutuhan kalori, maka dapat berakibat mengupayakan pemaksaan 
makan. Anak dapat menolak untuk makan makanan yang disajikan, sehingga mengakibatkan kegagalan anak dalam memenuhi kebutuhan energi dan nutrisi, kesulitan makan yang serius dapat dikaitkan dengan gangguan pertumbuhan. Menurut Leroy et al pada usia 2 sampai 5 tahun meningkatkan resiko stunting sebanyak $30 \%$ bila sudah terjadi gangguan tumbuh kembang pada 1000 hari kehidupannya (Leroy, Ruel, Habicht, \& Frongillo, 2014). Berbeda dengan hasil penelitian oleh Victor et al di Maharashtra, India bahwa kelompok usia 6 - 23 bulan berisiko 60\% lebih tinggi mengalami pertumbuhan yang jelek bahkan menjadi stunting apabila asupan, jenis dan frekuensi pada masa pemberian Makanan Pendamping ASI sehari - harinya tidak baik (OR 1,63; 95\% Cl 1,24 - 2,14). Ditandai dengan tidak adekuatnya dalam mengkonsumsi telur, produk susu olahan, buah dan sayuran (Aguayo, Nair, Badgaiyan, \& Krishna, 2016). Budaya merupakan salah satu faktor tidak langsung yang memengaruhi status gizi anak. Budaya merupakan salah satu faktor yang mempengaruhi sikap ibu di dalam menjalani masa kehamilannya, menjalani proses persalinan, serta dalam pengasuhan balita.
Budaya, tradisi, atau kebiasaan yang ada dalam masyarakat seperti pantangan makan, dan pola makan yang salah dapat mengakibatkan munculnya masalah gizi terutama bagi balita. Hal ini dapat berdampak terhadap pertumbuhan dan perkembangan balita (Adriani \& Wirjatmadi, 2012). Pola konsumsi masyarakat banjar sehari - hari yang umumnya memiliki proporsi karbohidrat lebih besar dibanding protein dan zat gizi lain serta rendahnya tingkat konsumsi sayur dan buah mempengaruhi kecukupan gizi balita di daerah tersebut. Usia balita yang semakin bertambah, menyebabkan kebutuhan akan zat gizi semakin meningkat pula dikarenakan proses tumbuh kembang sehingga bila kebutuhan gizi tidak terpenuhi dengan baik maka akan mempengaruhi kualitas pertumbuhan dan perkembangan balita.

Risiko untuk mengalami gangguan tumbuh (growth faltering) lebih besar pada bayi yang telah mengalami falter yaitu keadaan pada masa kehamilan dan prematuritas. Stunting yang disebabkan oleh growth faltering dan catch up growth yang tidak memadai, mencerminkan ketidakmampuan untuk mencapai pertumbuhan optimal. Tetapi jika diberikan 
asupan gizi yang adekuat maka pola pertumbuhan normal dapat terkejar (catch up). Ada beberapa tindakan yang dapat dilakukan untuk mengurangi prevalensi stunting. Pertama, mengoptimalkan praktek menyusui yang dimulai dengan inisiasi dini dan dilanjutkan dengan pemberian ASI eksklusif selama enam bulan. Pemberian ASI yang tepat akan memberikan perlindungan terhadap infeksi gastrointestinal yang dapat menyebabkan deplesi nutrisi yang parah. Kedua, intervensi yang paling efektif dalam mencegah stunting terutama pada masa pemberian makanan pendamping ASI yaitu setelah usia anak enam bulan adalah peningkatan kualitas makanan anak. Berbagai penelitian menunjukkan bahwa pemberian makanan yang bervariasi dan memberikan makanan bersumber hewani berhubungan dengan peningkatan pertumbuhan anak dan menurunkan stunting (Onyango, Borghi, De Onis, Del Carmen Casanovas, \& Garza, 2014). Ketiga, karena stunting yang terjadi berkaitan dengan lingkungan, sosial ekonomi, dan budaya maka intervensi gizi secara langsung harus terintegrasi dengan intervensi sensitif seperti pencegahan infeksi melalui penyediaan air bersih dan peningkatan
Perilaku Hidup Bersih dan Sehat (PHBS). Keterpaduan program gizi spesifik dan program gizi sensitif yang mampu mencapai ke sasaran sangat berkontribusi terhadap penurunan prevalensi stunting (Saint Ville, Po, Sen, Bui, \& Melgar-Quiñonez, 2019).

\section{Kesimpulan}

Panjang badan lahir pendek atau $<48 \mathrm{~cm}$ dan usia balita 24 - 36 bulan merupakan faktor risiko yang paling berhubungan secara bermakna dengan kejadian stunting pada balita usia 24-59 bulan di Puskesmas Cempaka Kota Banjarbaru.

\section{Daftar Pustaka}

Aguayo, V. M., \& Menon, P. (2016). Stop stunting: Improving child feeding, women's nutrition and household sanitation in South Asia. Maternal and Child Nutrition. 12(1). 3-11. doi: $10.1111 /$ mcn.12283

Adriani, M., dan Wirjatmadi, B. (2012). Pengantar gizi masyarakat. Jakarta: Kharisma Putra Utama.

Aguayo, V. M., Nair, R., Badgaiyan, N., \& Krishna, V. (2016). Determinants of stunting and poor linear growth in children under 2 years of age in India: An in-depth analysis of Maharashtra's comprehensive nutrition survey. Maternal and Child Nutrition. 12(1). 121-40. doi:10.1111/mcn.12259

Amaliah, N., Sari, K., \& Suryaputri, I. Y. (2016). Panjang Badan Lahir Pendek Sebagai Salah Satu Faktor Determinan Keterlambatan Tumbuh Kembang Anak Usia 6-23 Bulan Di 
Kelurahan Jaticempaka, Kecamatan Pondok Gede, Kota Bekasi. Jurnal Ekologi Kesehatan. 15(1). 43-55. doi: 10.22435/jek.v15i1.4959.43-55

Chowdhury, M. R. K., Rahman, M. S., Khan, M. M. H., Mondal, M. N. I., Rahman, M. M., \& Billah, B. (2016). Risk factors for child malnutrition in Bangladesh: A multilevel analysis of a nationwide population-based survey. Journal of Pediatrics. 172. 194-201 doi: 10.1016/j.jpeds.2016.01.023

Christian, P., Mullany, L. C., Hurley, K. M., Katz, J., \& Black, R. E. (2015). Nutrition and maternal, neonatal, and child health. Seminars in Perinatology. 39(5). 361-372. doi:10.1053/j.semperi.2015.06.009

Cutland, C. L., Lackritz, E. M., Mallett-Moore, T., Bardají, A., Chandrasekaran, R., Lahariya, C., ... Muñoz, F. M. (2017). Low birth weight: Case definition \& guidelines for data collection, analysis, and presentation of maternal immunization safety data. Vaccine. 35(48 Pt A). 6492-6500. https://doi.org/10.1016/j.vaccine.2017.01.0 49

Dinkes Kota Banjarbaru (2016). Laporan Tahuanan Hasil Pemantauan Status Gizi (PSG) Balita Per Puskesmas. Banjarbaru: Dinkes Banjarbaru.

Dinkes Kota Banjarbaru (2017). Laporan Tahuanan Hasil Pemantauan Status Gizi (PSG) Balita Per Puskesmas. Banjarbaru: Dinkes Banjarbaru

Desalegn, B. B., Kinfe, E., Fikre, K., \& Bosha, T. (2016). Stunting and Its Associated Factors in Under Five Years Old Children: The Case of Hawassa University Technology Villages, Southern Ethiopia. IOSR Journal of Environmental Science, Toxicology and Food
Technology. 10(11). 25-33. doi: $10.9790 / 2402-1011022531$

Hairunis, M. N., Rohmawati, N., \& Ratnawati, L. (2016). Determinan Kejadian Stunting Pada Anak Balita Di Wilayah Kerja Puskesmas Soromandi Kabupaten Bima Nusa Tenggara Barat. E-Jurnal Pustaka Kesehatan. 4(2), 323$329 . \quad$ diakses dari https://jurnal.unej.ac.id/index.php/JPK/articl e/view/3237

InfoDATIN. (2016). InfoDatin Situasi Balita Pendek 2016. Jakarta: Kemenkes RI. Diakses dari http://www.depkes.go.id/folder/view/01/str ucture-publikasi-pusdatin-info-datin.html

Kemenkes RI. (2018). Hasil Utama Riset Kesehatan Dasar Tahun 2018. Jakarta: Kementrian Kesehatan Republik Indonesia. Diakses dari http://www.depkes.go.id.

Kementerian Kesehatan. (2018). CEGAH, CEGAH, dan CEGAH: Suara Dunia Perangi Diabetes. Jakarta: In Biro Komunikasi Dan Pelayanan Masyarakat Kementerian Kesehatan Republik Indonesia. Diakses dari http://www.depkes.go.id.

Kusuma, K. E. (2013). Faktor Risiko Kejadian Stunting Pada Anak Usia 2-3 Tahun (Studi di Kecamatan Semarang Timur). Journal of Nutrition College. 2(4). 523-530. doi: 10.14710/jnc.v2i4.3735.

Leroy, J. L., Ruel, M., Habicht, J.-P., \& Frongillo, E. A. (2014). Linear Growth Deficit Continues to Accumulate beyond the First 1000 Days in Low- and Middle-Income Countries: Global Evidence from 51 National Surveys. The Journal of Nutrition. 144(9).1460-1466. doi: 10.3945/jn.114.191981

Ni'mah, K., \& Nadhiroh., S. R. (2015). Faktor yang Berhubungan dengan Kejadian Stunting Balita. Media Gizi Indonesia.10(1). 13-19. Diakses dari https://e- 
journal.unair.ac.id/MGl/article/download/31 $17 / 2264$.

Onyango, A. W., Borghi, E., De Onis, M., Del Carmen Casanovas, M., \& Garza, C. (2014). Complementary feeding and attained linear growth among 6-23-month-old children. Public Health Nutrition. 17(9).1975-1983. doi: $10.1017 /$ S1368980013002401

Rachmi, C. N., Agho, K. E., Li, M., \& Baur, L. A. (2016). Stunting, underweight and overweight in children aged 2.0-4.9 years in Indonesia: Prevalence trends and associated risk factors.
PLoS ONE. 11(5). 1-17. doi: 10.1371/journal.pone.0154756

Saint Ville, A., Po, J. Y. T., Sen, A., Bui, A., \& MelgarQuiñonez, H. (2019). Food security and the Food Insecurity Experience Scale (FIES): ensuring progress by 2030. Food Security. 11(3). 483-491. doi: 10.1007/s12571-01900936-9

Schmidt, C. W. (2014). Beyond malnutrition: The role of sanitation in stunted growth. Environmental Health Perspectives. 122(11). A298-A303. doi: 10.1289/ehp.122-A298 